Article

\title{
Container Type and Substrate Affect Root Zone Temperature and Growth of 'Green Giant' Arborvitae
}

\author{
Anthony L. Witcher ${ }^{1, *}$, Jeremy M. Pickens ${ }^{2}$ and Eugene K. Blythe ${ }^{3}$ \\ 1 Department of Agricultural and Environmental Sciences, Otis L. Floyd Nursery Research Center, \\ Tennessee State University, McMinnville, TN 37110, USA \\ 2 Department of Horticulture, Auburn University, Auburn, AL 36849, USA; jeremy.pickens@auburn.edu \\ 3 College of Agriculture, Auburn University, Auburn, AL 36849, USA; blythek@auburn.edu \\ * Correspondence: awitcher@tnstate.edu
}

Received: 20 December 2019; Accepted: 25 March 2020; Published: 7 April 2020

check for updates

\begin{abstract}
Root zone temperature (RZT) in nursery containers commonly exceeds ambient temperature during the growing season, negatively impacting crop growth and quality. Black nursery containers absorb radiant heat resulting in excessive RZT, yet other types of containers and different substrates can moderate RZT. We conducted studies in Tennessee and Alabama to evaluate the effects of container type and substrate on RZT and growth of 'Green Giant' arborvitae (Thuja standishii × plicata 'Green Giant'). Trade gallon arborvitae were transplanted into black, white, or air pruning containers filled with pine bark (PB) or 4 PB: 1 peatmoss (v:v) (PB:PM). Plants grown in PB:PM were larger and had greater shoot and root biomass than plants grown in $\mathrm{PB}$, likely due to increased volumetric water content. Plant growth response to container type varied by location, but white containers with PB:PM produced larger plants and greater biomass compared with the other container types. Root zone temperature was greatest in black containers and remained above $38{ }^{\circ} \mathrm{C}$ and $46{ }^{\circ} \mathrm{C}$ for $15 \%$ and $17 \%$ longer than white and air pruning containers, respectively. Utilizing light color containers in combination with substrates containing peatmoss can reduce RZT and increase substrate moisture content thus improving crop growth and quality.
\end{abstract}

Keywords: Thuja standishii $\times$ plicata; container production; nursery production; volumetric water content

\section{Introduction}

Container-grown nursery crops are subjected to extended periods of root zone heat stress throughout the growing season, negatively impacting crop growth and quality. The deleterious effects of high root zone temperature (RZT) have been observed historically in commercial container production. Self and Ward [1] observed less root growth of loquat (Eriobotrya japonica) on the south side of black metal cans where substrate temperature was $10^{\circ} \mathrm{C}$ to $15^{\circ} \mathrm{C}$ greater than ambient temperature $\left(30{ }^{\circ} \mathrm{C}\right)$. In nursery containers, maximum RZT can reach $54{ }^{\circ} \mathrm{C}$ which can damage crops even when exposed for short periods [2,3]. At RZTs above $46{ }^{\circ} \mathrm{C}$, direct injury to plants including immediate root cell damage can occur even with an exposure time under $30 \mathrm{~min}$. Indirect injury to plants can occur at RZTs above $38^{\circ} \mathrm{C}$, including interruption of physiological mechanisms which may not present visible signs of damage but lead to reduced growth $[4,5]$.

Many factors contribute to high RZT in container production. Nursery containers have a high surface-to-volume ratio, allowing excessive heat to be absorbed by the container and exchanged between the substrate through conduction [4]. Root zone temperature will vary within the container, with greater temperatures occurring in the region with direct exposure to the sun which will change throughout the growing season $[3,4]$. 
Container color, composition, or porosity can also affect RZT and plant growth. Dark-colored containers absorb more solar radiation than light-colored containers leading to excessive heat buildup in the substrate. Containers with a more porous exterior facilitate evaporation from the substrate and reduce heat exchange between the container wall and the substrate [6,7]. Markham et al. [3] evaluated the growth of red maple (Acer rubrum) and redbud (Cercis canadensis) along with RZT in conventional black containers and white painted containers. They reported RZT was $7.7^{\circ} \mathrm{C}$ greater in black containers compared with white containers and that red maple had 2.5 times greater root density in white containers. In the same study, they noted white containers had little effect on redbud growth suggesting sensitivity to supraoptimal RZT varies by plant species.

Another alternative to conventional containers is air pruning containers which are available from several manufacturers and are designed with circular openings or long open slots to prevent root circling and improve root branching. Arnold and McDonald [8] evaluated the growth of five tree species in air pruning and conventional black containers. Although results were species specific, plant height, trunk diameter, and root and shoot biomass were similar or improved in the air pruning container compared to the conventional container. In the same study, it was also reported RZT near the exterior edges was $5^{\circ} \mathrm{C}$ cooler in the air pruning container.

Container substrate porosity and moisture content are also factors in the rate of heat buildup or dissipation. Substrates with low air-filled porosity may improve heat energy diffusion through the substrate due to the physical connectivity of substrate particles. Water is an effective thermal conductor; thus, heat builds up more slowly in substrates with greater water content and minimizing temperature fluctuations in the substrate [4]. Pine bark (PB) is the most widely used substrate for nursery crops in the eastern United States and can be used alone or in combination with other components such as peatmoss $(\mathrm{PM})$ or sand $[9,10]$. Pine bark typically has a high proportion of drainable air space, whereas PM has greater water holding capacity. Nevertheless, PB physical properties can vary by region and source due to processing methods and aging which could affect crop growth [11]. The combination of PM with PB would increase substrate water holding capacity and possibly reduce RZT.

Plant species vary in response to RZT and duration of exposure. Eastern arborvitae (Thuja occidentalis) is sensitive to high RZT and performs best in the United States Department of Agriculture (USDA) plant hardiness zones two to seven where summer temperatures are more moderate [5,12]. In a similar species such as 'Green Giant' arborvitae (Thuja standishii × plicata 'Green Giant'), root temperature sensitivity has not been reported but it is more heat tolerant and adapted to various soil types and climates including areas with long durations of high summer temperatures [13].

Although the benefits of light-colored containers and air pruning containers have been well documented, commercial adoption of these products remains low. Substrates with increased water retention properties can improve crop growth, yet most nursery producers continue to use PB as the sole substrate component (personal observation). Previous research has focused on differences among container type or among substrates, but the combined effects of container type and substrate have not been reported. Determining which factors (container or substrate) or combination of factors have the greatest impact on crop growth could increase adoption of these practices.

The objective of this research was to evaluate the combined effects of container type and substrate on RZT and growth of 'Green Giant' arborvitae.

\section{Materials and Methods}

Two separate studies were conducted concurrently at the Tennessee State University Otis L. Floyd Nursery Research Center, McMinnville, TN (USDA Plant Hardiness Zone 7a) and the Auburn University Ornamental Horticulture Research Center, Mobile, AL, USA (USDA Plant Hardiness Zone $8 b$ ). The studies were conducted at two locations due to potential differences in environmental conditions which may affect plant growth including temperature and rainfall. The average daily temperature in Tennessee (TN) ranged from $20.8^{\circ} \mathrm{C}$ (September) to $26.7^{\circ} \mathrm{C}$ (July) and ranged from 
$24^{\circ} \mathrm{C}$ (May) to $27.3{ }^{\circ} \mathrm{C}$ (July) in Alabama (AL). Rainfall totaled $75.4 \mathrm{~cm}$ (TN) and $103.6 \mathrm{~cm}$ (AL) over the duration of each study.

Three different container types included black or white solid wall containers (11.3 L; PF1200; Nursery Supplies Inc., Kissimmee, FL, USA) and an air pruning container (10.5 L; \#5 Rediroot; Nursery Source Inc., Boring, OR, USA). Two substrates were evaluated in combination with each container type (for a total of six treatments) and included PB and 4 PB: 1 peatmoss (v:v) (PB:PM). Pine bark was obtained from Morton's Horticultural Products (McMinnville, TN, USA) and from Longleaf Mulch (Semmes, AL, USA) for the TN and AL studies, respectively. Both substrates were amended (per $1 \mathrm{~m}^{3}$ ) with $5.9 \mathrm{~kg} 18 \mathrm{~N}-2.6 \mathrm{P}-6.6 \mathrm{~K}$ controlled-release fertilizer (18-6-8 Nutricote ${ }^{\circledR}$ Total Type 180; Florikan USA, Sarasota, FL, USA), $3.6 \mathrm{~kg}$ dolomitic limestone, and $0.9 \mathrm{~kg}$ micronutrient granules (Micromax; ICL Specialty Fertilizers, Summerville, SC, USA). Trade gallon (2.4 L) 'Green Giant' arborvitae were transplanted on 19 April 2017 (AL) or 27 April 2017 (TN) into each treatment with 12 replicates (for a total of 72 individual experimental units) and plants were arranged on a gravel container pad in a randomized complete block design. To provide maximum container surface area to sunlight, plants were spaced $0.9 \mathrm{~m}$ apart.

Separate irrigation zones were used for each treatment to monitor and adjust irrigation application rates. Plants were irrigated daily using a modified dribble ring $(15.2 \mathrm{~cm}$ diameter; Dramm Corp., Manitowoc, WI) fitted with a pressure-compensating emitter $\left(8 \mathrm{~L} \mathrm{~h}^{-1}\right.$; Netafim USA, Fresno, CA). Irrigation application volume for each treatment was adjusted every two weeks to a target leaching fraction of $10 \%$ to $20 \%$. Decagon 5TE (AL) and 5TM (TN) sensors and EM50 data loggers (Decagon Devices Inc., Pullman, WA) were used to measure and record RZT and volumetric water content $\left(\right.$ VWC; $\mathrm{m}^{3} \cdot \mathrm{m}^{-3}$ ) every $15 \mathrm{~min}$ throughout both studies. Sensors ( 1 per container; $\mathrm{n}=3$ ) were positioned vertically approximately $4.3 \mathrm{~cm}$ from the south-facing container sidewall and placed midway between the substrate surface and bottom of the container. Plant height and diameter were measured at 0,59 , 138, and 166 days after planting (DAP) in AL and 0, 69, 95, 120, and 173 DAP in TN. Growth index was calculated [(height + width at widest point + perpendicular width) /3] and increase in plant height and growth index was also reported (increase $=$ final - initial). The studies were terminated at $166(\mathrm{AL})$ and $173(\mathrm{TN})$ DAP and plants were destructively harvested. Shoot dry weight $(\mathrm{n}=12)$ and root dry weight $(\mathrm{n}=4)$ were measured after samples were oven-dried at $70^{\circ} \mathrm{C}$ for approximately 7 days. Substrate $\mathrm{pH}$ and electrical conductivity (EC) were recorded using the pour-through method [14] at $52,97,146$, and $166 \mathrm{DAP}(\mathrm{AL})$ and at 60, 95, and $120 \mathrm{DAP}(\mathrm{TN})$. The percentage of time roots were exposed to temperatures above critical thresholds $\left(38^{\circ} \mathrm{C}\right.$ and $\left.46^{\circ} \mathrm{C}\right)$ mentioned by Ingram et al. (2015) was calculated using the total number of data recordings during daylight hours. Substrate physical properties $(n=3)$ including air space, container capacity, total porosity, and bulk density were determined using porometer analysis [15].

Multi-factor data were analyzed with linear mixed models using the GLIMMIX procedure of SAS (Version 9.3; SAS Institute, Inc., Cary, NC, USA) by first testing for an interaction between treatment factors (container type and substrate). When there was an interaction between treatment factors, levels of container type were compared within each substrate. Porometer data were analyzed with linear models using the GLIMMIX procedure of SAS. $P$-values for all simultaneous comparisons were adjusted using the Tukey method to maintain an overall significance level of $\alpha=0.05$.

\section{Results}

\subsection{Plant Growth}

In the TN study, there was an interaction between container type and substrate for final plant height and height increase (Table 1). Both height and height increase were greatest for plants in the white container for PB:PM. White containers with PB:PM also produced plants with the greatest growth index (final and increase) (Table 2). Overall, plants grown in PB:PM produced more shoot and root dry weight (biomass) compared with plants grown in PB. White and black containers had similar shoot 
and root dry weight in PB but shoot dry weight was greatest in white containers for PB:PM. In the white container, shoot dry weight and root dry weight were 56\% and 68\% greater, respectively, for PB:PM compared with PB. In PB, final growth index and increase were similar for plants in black and white containers. Regardless of substrate, however, plants were shortest in the air pruning container.

Table 1. Plant height and height increase $(n=12)$ of 'Green Giant' arborvitae grown in different types of containers and substrates in Tennessee and Alabama.

\begin{tabular}{|c|c|c|c|c|c|c|c|}
\hline & & \multicolumn{3}{|c|}{ Plant Height (cm) } & \multicolumn{3}{|c|}{ Plant Height (cm) } \\
\hline & & $69 \operatorname{DAP}^{x}$ & 173 DAP & Increase $^{w}$ & 59 DAP & 166 DAP & Increase \\
\hline & & \multicolumn{3}{|c|}{ Tennessee } & \multicolumn{3}{|c|}{ Alabama } \\
\hline & & \multicolumn{6}{|c|}{ Significance of treatment factors } \\
\hline Container $(\mathrm{C})^{\mathrm{z}}$ & & 0.0055 & $<0.0001$ & $<0.0001$ & 0.1523 & $<0.0001$ & $<0.0001$ \\
\hline Substrate (S) ${ }^{y}$ & & 0.8889 & $<0.0001$ & $<0.0001$ & 0.7328 & 0.0267 & 0.0053 \\
\hline \multirow[t]{2}{*}{ C by $S$} & & 0.1817 & 0.0006 & 0.0003 & 0.4744 & 0.9544 & 0.9757 \\
\hline & & \multicolumn{6}{|c|}{ Least squares means for main effects } \\
\hline \multirow[t]{4}{*}{ Substrate } & Container & & & & & & \\
\hline & Black & $69.3 \mathrm{ab}^{\mathrm{v}}$ & - & - & $72.1 \mathrm{a}$ & $78.2 \mathrm{~b}$ & $16.1 \mathrm{~b}$ \\
\hline & White & $71.8 \mathrm{a}$ & - & - & $72.9 \mathrm{a}$ & $92.7 \mathrm{a}$ & $31.3 \mathrm{a}$ \\
\hline & Air & $66.9 \mathrm{~b}$ & - & - & $69.3 \mathrm{a}$ & $75.1 \mathrm{~b}$ & $14.0 \mathrm{~b}$ \\
\hline $\mathrm{PB}$ & & $69.4 \mathrm{a}$ & - & - & $71 . \overline{2} \mathrm{a}$ & $79.6 \mathrm{~b}$ & $17.6 \mathrm{~b}$ \\
\hline PB:PM & & $69.3 \mathrm{a}$ & - & - & $71.7 \mathrm{a}$ & $84.4 \mathrm{a}$ & $23.3 \mathrm{a}$ \\
\hline & & \multicolumn{6}{|c|}{ Treatment least squares means grouped by substrate } \\
\hline Substrate & Container & & & & & & \\
\hline \multirow{3}{*}{$\mathrm{PB}$} & Black & 67.8 & $85.8 \mathrm{a}$ & $27.3 \mathrm{a}$ & 70.9 & 75.8 & 13.4 \\
\hline & White & 72.3 & $83.3 \mathrm{a}$ & $21.8 \mathrm{ab}$ & 73.9 & 90.7 & 28.6 \\
\hline & Air & 68.2 & $75.0 \mathrm{~b}$ & $14.9 \mathrm{~b}$ & 68.7 & 72.3 & 10.8 \\
\hline \multirow{3}{*}{ PB:PM } & Black & 70.7 & $99.2 \mathrm{~b}$ & $41.0 \mathrm{~b}$ & 73.3 & 80.7 & 18.8 \\
\hline & White & 71.4 & $114.8 \mathrm{a}$ & $56.0 \mathrm{a}$ & 71.8 & 94.7 & 34.1 \\
\hline & Air & 65.7 & 88.2 c & $32.5 \mathrm{c}$ & 70 & 77.9 & 17.2 \\
\hline
\end{tabular}

${ }^{\mathrm{z}}$ Container type: Black and White-standard solid wall (11.3 L; PF1200; Nursery Supplies Inc., Kissimmee, FL, USA); Air-air pruning (10.5 L; \#5 Rediroot; NurserySource Inc., Boring, OR, USA). y Substrate: Pine bark alone (PB) or combined (v:v) with peatmoss (PB:PM; 4 pine bark: 1 peatmoss). ${ }^{\mathrm{x}}$ DAP $=$ days after planting. ${ }^{\mathrm{W}}$ Increase $=$ final plant height-initial plant height. ${ }^{\mathrm{v}}$ When the interaction term in the model is not significant $(P>0.10)$, main effects means for levels within each treatment factor followed by the same lower-case letter are not significantly different using the Tukey method for multiple comparisons $(\alpha=0.05)$. When the interaction term in the model is significant $(P \leq 0.10)$, simple effects means (treatment means for container grouped within substrate) followed by the same lower-case letter are not significantly different using the Tukey method for multiple comparisons $(\alpha=0.05)$; otherwise, the treatment means are presented without letter groupings for informational purposes.

In the AL study after approximately two months of growth, plant height was similar between the two substrates and among the three types of containers (Table 1). At the end of the study, plant height was greater in PB:PM compared to PB and greatest in the white container (by over 18\%). The plant height increase was also greatest in white containers and PB:PM. Plant growth index followed a similar trend with white containers and PB:PM producing larger plants throughout the study and the greatest growth index increase (Table 2). Although the white container with PB:PM tended to produce taller plants, shoot dry weight was similar among all container types in PB:PM and similar between black and white containers in PB. Container type did not have an effect on root dry weight, but root dry weight was $12 \%$ greater in PB:PM compared to PB. 
Table 2. Plant growth index $(n=12)$, growth index increase and dry weight (shoot and root) of 'Green Giant' arborvitae grown in different types of containers and substrates in Tennessee and Alabama.

\begin{tabular}{|c|c|c|c|c|c|c|c|c|c|c|c|}
\hline & & \multicolumn{3}{|c|}{ Growth Index ${ }^{x}$} & \multirow{2}{*}{$\begin{array}{c}\text { Shoot Dry } \\
\text { wt (g) }\end{array}$} & \multirow{2}{*}{$\begin{array}{l}\text { Root Dry } \\
\text { wt (g) }\end{array}$} & \multicolumn{3}{|c|}{ Growth Index } & \multirow{2}{*}{$\begin{array}{c}\text { Shoot Dry } \\
\text { wt (g) }\end{array}$} & \multirow{2}{*}{$\begin{array}{c}\text { Root Dry } \\
\text { wt (g) }\end{array}$} \\
\hline & & $69 \mathrm{DAP}^{\mathrm{w}}$ & 173 DAP & Increase $^{\mathrm{v}}$ & & & 59 DAP & 166 DAP & Increase & & \\
\hline & & \multicolumn{5}{|c|}{ Tennessee } & \multicolumn{4}{|c|}{ Alabama } & \\
\hline & & \multicolumn{10}{|c|}{ Significance of treatment factors } \\
\hline Container $(C)^{z}$ & & 0.005 & $<0.0001$ & $<0.0001$ & $<0.0001$ & 0.0084 & 0.55 & $<0.0001$ & $<0.0001$ & 0.0002 & 0.3203 \\
\hline Substrate $(S)$ y & & 0.6342 & $<0.0001$ & $<0.0001$ & $<0.0001$ & $<0.0001$ & 0.0219 & 0.0002 & 0.0025 & $<0.0001$ & 0.0452 \\
\hline \multirow[t]{2}{*}{ C by S } & & 0.4362 & 0.0002 & $<0.0001$ & $<0.0001$ & 0.0332 & 0.7646 & 0.6223 & 0.7424 & 0.0497 & 0.2689 \\
\hline & & \multicolumn{10}{|c|}{ Least squares means for main effects } \\
\hline \multirow[t]{4}{*}{ Substrate } & Container & & & & & & & & & & \\
\hline & Black & $56.5 \mathrm{ab}^{\mathrm{u}}$ & - & - & - & - & $52.3 \mathrm{a}$ & $56.9 \mathrm{~b}$ & $15.2 \mathrm{~b}$ & - & 507 a \\
\hline & White & $58.1 \mathrm{a}$ & - & - & - & - & $53.0 \mathrm{a}$ & $63.3 \mathrm{a}$ & $22.4 \mathrm{a}$ & - & $560 \mathrm{a}$ \\
\hline & Air & $54.4 \mathrm{~b}$ & - & - & - & - & $51.7 \mathrm{a}$ & $55.2 \mathrm{~b}$ & $13.8 \mathrm{~b}$ & - & $534 \mathrm{a}$ \\
\hline $\mathrm{PB}$ & & $56.1 \mathrm{a}$ & - & - & - & - & $51.3 \mathrm{~b}$ & $56.3 \mathrm{~b}$ & $15.3 \mathrm{~b}$ & - & $503 \mathrm{~b}$ \\
\hline \multirow[t]{2}{*}{ PB:PM } & & $56.5 \mathrm{a}$ & - & - & - & - & $53.4 \mathrm{a}$ & $60.7 \mathrm{a}$ & $19.0 \mathrm{a}$ & - & $564 \mathrm{a}$ \\
\hline & & \multicolumn{10}{|c|}{ Treatment least squares means grouped by substrate } \\
\hline Substrate & Container & & & & & & & & & & \\
\hline \multirow{3}{*}{ PB } & Black & 56.5 & $68.9 \mathrm{a}$ & $26.6 \mathrm{a}$ & $330 \mathrm{a}$ & $629 a$ & 51.3 & 55.1 & 12.8 & $162 \mathrm{a}$ & 508.5 \\
\hline & White & 58.4 & $68.4 \mathrm{a}$ & $25.1 \mathrm{a}$ & 299 a & $487 \mathrm{ab}$ & 52.3 & 61.5 & 21 & $170 \mathrm{a}$ & 506.5 \\
\hline & Air & 53.4 & $61.9 \mathrm{~b}$ & $21.4 \mathrm{~b}$ & $191 \mathrm{~b}$ & $366 \mathrm{~b}$ & 50.2 & 52.2 & 12 & $120 \mathrm{~b}$ & 494 \\
\hline \multirow{3}{*}{ PB:PM } & Black & 56.4 & $74.9 \mathrm{~b}$ & $33.5 \mathrm{~b}$ & $383 \mathrm{~b}$ & $698 a$ & 53.4 & 58.8 & 17.7 & $195 \mathrm{a}$ & 504.5 \\
\hline & White & 57.8 & $83.8 \mathrm{a}$ & $42.2 \mathrm{a}$ & $466 \mathrm{a}$ & $820 \mathrm{a}$ & 53.7 & 65.1 & 23.7 & $201 \mathrm{a}$ & 614 \\
\hline & Air & 55.4 & $72.6 \mathrm{~b}$ & $31.8 \mathrm{~b}$ & $361 \mathrm{~b}$ & 653 a & 53.3 & 58.1 & 15.5 & $186 \mathrm{a}$ & 574 \\
\hline
\end{tabular}

${ }^{\mathrm{z}}$ Container type: Black and White—standard solid wall (11.3 L; PF1200; Nursery Supplies Inc., Kissimmee, FL); Air—air pruning (10.5 L; \#5 Rediroot; NurserySource Inc., Boring, OR). y Substrate: Pine bark alone (PB) or combined (v:v) with peatmoss (PB:PM; 4 pine bark: 1 peatmoss). ${ }^{x}$ Growth index $=$ (height + width at widest point + perpendicular width) $/ 3$. ${ }^{\text {w }}$ DAP $=$ days after planting. ${ }^{\mathrm{v}}$ Increase $=$ final growth index-initial growth index. ${ }^{\mathrm{u}}$ When the interaction term in the model is not significant $(P>0.10)$, main effects means for levels within each $=$ days after planting. "Increase $=$ final growth index-initial growth index. "When the interaction term in the model is not significant $(P>0.10)$, main effects means for levels within each
treatment factor followed by the same lower-case letter are not significantly different using the Tukey method for multiple comparisons $(\alpha=0.05)$. When the interaction term in the model is significant $(P \leq 0.10)$, simple effects means (treatment means for container grouped within substrate) followed by the same lower-case letter are not significantly different using the Tukey method for multiple comparisons $(\alpha=0.05)$; otherwise, the treatment means are presented without letter groupings for informational purposes. 


\subsection{Substrate Chemical and Physical Properties}

Substrate $\mathrm{pH}$ ranged from 5.3 to $6.4(\mathrm{TN})$ and from 5.4 to 6.7 (AL) for all treatments in each study (data not shown), remaining within the recommended range of 4.5 to 6.5 [16] except at 52 DAP in AL. Substrate $\mathrm{pH}$ was only 0.3 units lower in PB:PM at 95 and 120 DAP in TN and the addition of $\mathrm{PM}$ had no effect on substrate $\mathrm{pH}$ in the AL study. Substrate EC varied among treatments in the TN study but no clear trend was observed (data not shown). Conversely, substrate and container type had no effect on substrate EC in the AL study except at 146 DAP with substrate EC being greatest in the black container.

Substrate container capacity increased $12 \%(\mathrm{TN})$ and $7 \%(\mathrm{AL})$ with the addition of PM compared to PB (Table 3). Substrate air space was greater for PB in the TN study, being reduced by $8 \%$ in PB:PM. Substrate air space was similar for substrates in the AL study, and air space was overall lower in PB from AL compared with TN.

Table 3. Physical properties $(n=3)$ of substrates for production of 'Green Giant' arborvitae in Tennessee and Alabama.

\begin{tabular}{|c|c|c|c|c|}
\hline Substrate $^{\mathrm{z}}$ & Air Space ${ }^{y}$ & Container Capacity & Total Porosity & Bulk Density \\
\hline & \multicolumn{3}{|c|}{ (\% volume) } & $\left(\mathrm{g} \cdot \mathrm{cm}^{-3}\right)$ \\
\hline & \multicolumn{4}{|c|}{ Tennessee } \\
\hline PB & $30.4 \mathrm{a}^{\mathrm{x}}$ & $42.8 \mathrm{~b}$ & $73.2 \mathrm{a}$ & $0.233 \mathrm{a}$ \\
\hline PB:PM & $21.8 \mathrm{~b}$ & $54.7 \mathrm{a}$ & $76.5 \mathrm{a}$ & $0.226 \mathrm{a}$ \\
\hline & \multicolumn{4}{|c|}{ Alabama } \\
\hline $\mathrm{PB}$ & $25.4 \mathrm{a}$ & $41.1 \mathrm{~b}$ & $66.6 \mathrm{a}$ & $0.267 \mathrm{a}$ \\
\hline PB:PM & $21.7 \mathrm{a}$ & $48.9 \mathrm{a}$ & $70.6 \mathrm{a}$ & $0.259 \mathrm{a}$ \\
\hline
\end{tabular}

${ }^{\mathrm{z}}$ Substrate: Pine bark alone (PB) or combined (v:v) with peatmoss (PB:PM; 4 pine bark: 1 peatmoss). ${ }^{\text {y }}$ Data obtained using the North Carolina State University porometer method (Fonteno and Harden, 2010). ${ }^{x}$ Means followed by the same letter within a location are not significantly different $(\alpha=0.05)$.

\subsection{Root Zone Temperature and Volumetric Water Content}

Substrate did not have an effect on the percentage of time at or above specific threshold temperatures $\left(38^{\circ} \mathrm{C}\right.$ and $\left.46^{\circ} \mathrm{C}\right)$ in either study, but black containers produced the greatest RZT and remained above the critical thresholds far longer than the other container types (Table 4). In TN, RZT in the black container remained above $38^{\circ} \mathrm{C}$ for over $19 \%$ of the time which was $15 \%$ and $17 \%$ longer than white and air pruning containers, respectively. Although RZT in black containers only remained at or above $46^{\circ} \mathrm{C}$ for $0.1 \%$ of the time, RZT in air pruning and white containers remained below $46^{\circ} \mathrm{C}$ throughout the study. In $\mathrm{AL}$, there was an interaction between container type and substrate for a percentage of time at or above $38^{\circ} \mathrm{C}$. Root zone temperature in the black container remained above $38{ }^{\circ} \mathrm{C}$ for over $21 \%$ of the time (regardless of substrate), over $13 \%$ longer than the other container types. Root zone temperature in air pruning and white containers did not reach the $46^{\circ} \mathrm{C}$ threshold but RZT in black containers remained at this threshold for nearly $2 \%$ of the time.

Volumetric water content was lowest in the air pruning container throughout most of the TN study (Table 5). Volumetric water content was similar for black and white containers in June and July, but black containers had the greatest VWC compared with the other container types in August and September. Substrate also affected VWC, with PB:PM maintaining greater VWC throughout the study. Similar trends were observed for VWC in the AL study, with VWC greater in black containers compared to the air pruning containers and VWC was also greater in PB:PM throughout the study (data not shown). 
Table 4. Percent of time $(n=3)$ substrate temperature remained at or above critical thresholds $\left(38^{\circ} \mathrm{C}\right.$ and $46^{\circ} \mathrm{C}$ ) during daylight hours for 'Green Giant' arborvitae grown in different types of containers and substrates in Tennessee and Alabama.

\begin{tabular}{|c|c|c|c|c|c|}
\hline & & $38^{\circ} \mathrm{C}(\%)$ & $46^{\circ} \mathrm{C}(\%)$ & $38^{\circ} \mathrm{C}(\%)$ & $46^{\circ} \mathrm{C}(\%)$ \\
\hline & & \multicolumn{2}{|c|}{ Tennessee } & \multicolumn{2}{|c|}{ Alabama } \\
\hline & & \multicolumn{4}{|c|}{ Significance of treatment factors } \\
\hline \multicolumn{2}{|l|}{ Container $(C)^{\mathrm{z}}$} & $<0.0001$ & 0.0221 & $<0.0001$ & $<0.0001$ \\
\hline \multicolumn{2}{|l|}{ Substrate (S) y } & 0.5229 & 0.5144 & 0.7182 & 0.6128 \\
\hline \multirow{2}{*}{\multicolumn{2}{|c|}{ C by $\mathrm{S}$}} & 0.397 & 0.5864 & 0.047 & 0.6464 \\
\hline & & \multicolumn{4}{|c|}{ Least squares means for main effects } \\
\hline \multirow[t]{2}{*}{ Substrate } & \multicolumn{5}{|l|}{ Container } \\
\hline & Black & $19.4 \mathrm{a}^{\mathrm{x}}$ & $0.1 \mathrm{a}$ & - & $1.93 \mathrm{a}$ \\
\hline & White & $4.2 \mathrm{~b}$ & $0.0 \mathrm{~b}$ & - & $0.00 \mathrm{~b}$ \\
\hline \multirow{4}{*}{\multicolumn{2}{|c|}{$\begin{array}{c}\text { PB } \\
\text { PB:PM }\end{array}$}} & $2.7 \mathrm{~b}$ & $0.0 \mathrm{~b}$ & - & $0.00 \mathrm{~b}$ \\
\hline & & $7.9 \mathrm{a}$ & $0.0 \mathrm{a}$ & - & $0.85 \mathrm{a}$ \\
\hline & & $8.3 \mathrm{a}$ & $0.0 \mathrm{a}$ & - & $0.43 \mathrm{a}$ \\
\hline & & \multicolumn{4}{|c|}{ Treatment least squares means grouped by substrate } \\
\hline \multirow[t]{2}{*}{ Substrate } & \multicolumn{5}{|c|}{ 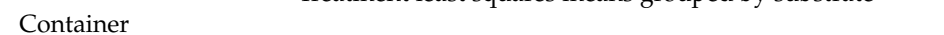 } \\
\hline & Black & 20.2 & 0.0 & $24.2 \mathrm{a}$ & 2.5 \\
\hline \multirow[t]{2}{*}{ PB } & White & 5.1 & 0.0 & $8.4 \mathrm{~b}$ & 0.0 \\
\hline & Air & 2.5 & 0.0 & $5.5 \mathrm{c}$ & 0.0 \\
\hline \multirow{3}{*}{ PB:PM } & Black & 18.8 & 0.1 & $21.6 \mathrm{a}$ & 1.3 \\
\hline & White & 3.2 & 0.0 & $7.2 \mathrm{~b}$ & 0.0 \\
\hline & Air & 2.9 & 0.0 & $7.8 \mathrm{~b}$ & 0.0 \\
\hline
\end{tabular}

${ }^{\mathrm{z}}$ Container type: Black and White-standard solid wall (11.3 L; PF1200; Nursery Supplies Inc., Kissimmee, FL); Air-air pruning (10.5 L; \#5 Rediroot; NurserySource Inc., Boring, OR). ${ }^{y}$ Substrate: Pine bark alone (PB) or combined (v:v) with peatmoss (PB:PM; 4 pine bark: 1 peatmoss). ${ }^{x}$ When the interaction term in the model is not significant $(P>0.10)$, main effects means for levels within each treatment factor followed by the same lower-case letter are not significantly different using the Tukey method for multiple comparisons $(\alpha=0.05)$. When the interaction term in the model is significant $(P \leq 0.10)$, simple effects means (treatment means for container grouped within substrate) followed by the same lower-case letter are not significantly different using the Tukey method for multiple comparisons $(\alpha=0.05)$; otherwise, the treatment means are presented without letter groupings for informational purposes.

Table 5. Average daytime volumetric water content $(n=3)$ over a four-month period for 'Green Giant' arborvitae grown in different types of containers and substrates in Tennessee.

\begin{tabular}{|c|c|c|c|c|c|}
\hline & & \multicolumn{4}{|c|}{ Volumetric Water Content $\left(\mathrm{m}^{3} \cdot \mathrm{m}^{-3}\right)$} \\
\hline & & June & July & August & September \\
\hline & & \multicolumn{4}{|c|}{ Significance of treatment factors } \\
\hline Container $(C)^{\mathrm{z}}$ & & 0.0274 & 0.0044 & 0.0006 & 0.0007 \\
\hline Substrate $(S)^{y}$ & & 0.0021 & 0.0226 & 0.0176 & 0.0183 \\
\hline \multirow[t]{2}{*}{$\mathrm{C}$ by $\mathrm{S}$} & & 0.0175 & 0.2421 & 0.7409 & 0.2288 \\
\hline & & \multicolumn{4}{|c|}{ Least squares means for main effects } \\
\hline \multirow[t]{2}{*}{ Substrate } & \multicolumn{5}{|l|}{ Container } \\
\hline & Black & - & $0.314 \mathrm{a}^{\mathrm{x}}$ & $0.320 \mathrm{a}$ & $0.312 \mathrm{a}$ \\
\hline & White & - & $0.274 \mathrm{a}$ & $0.220 \mathrm{~b}$ & $0.201 \mathrm{~b}$ \\
\hline & Air & - & $0.178 \mathrm{~b}$ & $0.131 \mathrm{c}$ & $0.139 \mathrm{c}$ \\
\hline & & - & $0.214 \mathrm{~b}$ & $0.180 \mathrm{~b}$ & $\overline{0} \overline{176} \mathrm{~b}$ \\
\hline \multirow{2}{*}{ PB:PM } & & - & $0.283 \mathrm{a}$ & $0.247 \mathrm{a}$ & $0.240 \mathrm{a}$ \\
\hline & & \multicolumn{4}{|c|}{ Treatment least squares means grouped by substrate } \\
\hline Substrate & Container & & & & \\
\hline \multirow{3}{*}{$\mathrm{PB}$} & Black & $0.270 \mathrm{a}$ & 0.283 & 0.3 & 0.307 \\
\hline & White & $0.319 \mathrm{a}$ & 0.266 & 0.187 & 0.159 \\
\hline & Air & $0.152 \mathrm{~b}$ & 0.117 & 0.093 & 0.105 \\
\hline \multirow{3}{*}{ PB:PM } & Black & $0.367 \mathrm{a}$ & 0.346 & 0.341 & 0.316 \\
\hline & White & $0.323 \mathrm{a}$ & 0.286 & 0.269 & 0.265 \\
\hline & Air & $0.342 \mathrm{a}$ & 0.238 & 0.169 & 0.173 \\
\hline
\end{tabular}

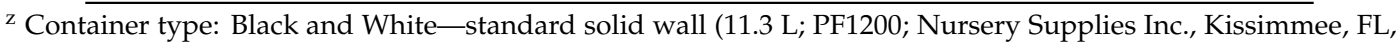
USA); Air-air pruning (10.5 L; \#5 Rediroot; NurserySource Inc., Boring, OR, USA). ${ }^{y}$ Substrate: Pine bark alone $(\mathrm{PB})$ or combined (v:v) with peatmoss (PB:PM; 4 pine bark: 1 peatmoss). ${ }^{\times}$When the interaction term in the model is not significant $(P>0.10)$, main effects means for levels within each treatment factor followed by the same lower-case letter are not significantly different using the Tukey method for multiple comparisons $(\alpha=0.05)$. When the interaction term in the model is significant $(P \leq 0.10)$, simple effects means (treatment means for container grouped within substrate) followed by the same lower-case letter are not significantly different using the Tukey method for multiple comparisons $(\alpha=0.05)$; otherwise, the treatment means are presented without letter groupings for informational purposes. 


\section{Discussion}

Overall, arborvitae grew taller and produced more biomass in white containers with PB:PM. Plants in air pruning containers were smaller than those grown in black or white containers (regardless of substrate), but more growth occurred when PB:PM was used. The air pruning and white containers provided a lower RZT for plants throughout both studies, minimizing heat-related stress which likely led to reduced plant growth in the black container. Maximum RZT (data not shown) was reduced from $5{ }^{\circ} \mathrm{C}$ to $8{ }^{\circ} \mathrm{C}$ in the air pruning and white containers. Root zone temperature in the black container reached $46{ }^{\circ} \mathrm{C}(\mathrm{TN})$ and $51{ }^{\circ} \mathrm{C}(\mathrm{AL})$, while $\mathrm{RZT}$ in the air pruning and white containers reached a maximum of $41^{\circ} \mathrm{C}(\mathrm{TN})$ and $43^{\circ} \mathrm{C}(\mathrm{AL})$. These results support previous research documenting increased growth in white containers due to the deleterious effects of supraoptimal RZT. Root zone temperatures can commonly exceed $54{ }^{\circ} \mathrm{C}$ in container-grown crops, but RZT near $38^{\circ} \mathrm{C}$ can cause indirect injury to plants leading to reduced shoot and root growth, increased water stress, interruption of physiological mechanisms (photosynthesis and respiration, and increased susceptibility to pathogens [3,4,7]. In our study, fewer roots were observed on the south-facing side of the solid wall containers, regardless of container color, suggesting supraoptimal RZT prevents root growth and development near the container sidewall even in light color containers.

Although air pruning containers had lower RZT, plant growth and biomass were consistently lower than plants in white containers. These results contradict previous work by Arnold and McDonald [8] where tree growth of several tree species was similar or superior in the air pruning container compared to the black container. In the present study, black and white containers had a $7 \%$ larger volume than the air pruning container which could have attributed to some of the reduced plant growth observed in the air pruning container. The physical design of the air pruning container likely also contributed to the reduced growth. The air pruning container was designed with open slots, aligned longitudinally around the container side wall, to prevent root circling and improve root branching and growth. The slots increase aeration which prevents buildup of heat, resulting in moderated RZT closer to ambient conditions. In air pruning containers, a larger portion of substrate surface is exposed to the outside environment resulting in more rapid drying out due to increased evaporation through solar radiation and air flow. Arnold and McDonald [8] also noted the air pruning container moderated RZT and that plants in the air pruning container dried out sooner. In the present study, VWC was lowest in the air pruning container which limited the amount of plant-available water and likely led to the reduced plant growth. Irrigation volume was calculated based on leaching fraction and applied once daily, thus the substrate in air pruning containers dried more rapidly after irrigation compared with the solid wall containers and likely never reached container capacity. Overall, black and white containers received more irrigation volume (13\% and $38 \%$, respectively; data not shown) compared to the air pruning containers corresponding to the observed differences in arborvitae growth. Therefore, growers using air pruning containers should utilize more frequent (cyclic) irrigation to maximize VWC throughout the day and reduce water-related stress especially in substrates with high air-filled porosity and lower water holding capacity.

Peatmoss increased substrate container capacity by up to $12 \%$ compared to PB alone resulting in PB:PM having at least 7\% greater VWC throughout both studies. On average, plants grown in PB:PM received 90\% more irrigation volume compared PB. The combined benefits of greater water retention and irrigation volume corresponded to superior plant growth in PB:PM. Peatmoss has greater container capacity and easily available water compared to $\mathrm{PB}$, likely due to a higher proportion of macropores and a lower proportion of fine particles in PB [17]. The PB and PM for each study were obtained from different sources which led to slight differences in physical properties for each study. Pine bark physical properties can vary due to a number of factors including source, age, and processing method [11]. Nevertheless, the addition of PM provided PB:PM with more plant-available water resulting in overall improved plant growth at both locations.

Peatmoss typically has a lower inherent $\mathrm{pH}$ compared to PB. It has been shown that increasing the percentage of PM in PB does not increase cation exchange capacity (and thus nutrient retention) on a 
volumetric basis $[9,18]$. Johnson et al. [18] reported an increase in soluble salt level with an increasing proportion of PM in PB substrates despite no increase in CEC. In our studies, PB:PM was composed of $20 \%$ PM but substrate $\mathrm{pH}$ was not negatively affected and differences in EC between substrates were not observed. However, EC was generally lower for PB:PM in both studies and a lack of significance might be due to sample variation and small sample size $(n=4)$.

Root zone temperature was not affected by substrate in the present studies, yet substrate porosity and VWC may contribute to the rate of heat buildup and dissipation in a substrate. Amoroso et al. [19] reported RZT was greater in substrates irrigated to $100 \%$ container capacity compared to $30 \%$ container capacity. In their study, the substrate was composed of 80\% PM which typically has smaller particle size and lower air space compared to PB. Martin and Ingram [20] suggested substrates with lower pore space combined with greater VWC (25\% to 40\%) could dissipate heat more effectively. As a result, substrate temperature would increase at a slower rate and maintain a lower RZT overall. Although PB:PM had greater VWC, there was very little difference in substrate total porosity compared to PB alone which may have minimized thermal dissipation in this study. Plants were irrigated once daily at 12 pm, thus VWC may have been too low during the hottest portion of the day for heat to effectively dissipate. Applying irrigation multiple times throughout the afternoon would increase VWC over a longer period and possibly improve heat dissipation from the substrate.

All the arborvitae plants grown in these studies were marketable, but plants grown in PB:PM grew significantly larger and were visually superior in quality (Figure 1). Plants in PB:PM benefited from overall greater VWC and which remained higher throughout the day compared with PB. Peatmoss is more expensive than $\mathrm{PB}$ and requires additional equipment for mixing into the substrate, but the added benefits (water retention and availability) could result in higher quality crops that reach a finished size more quickly. For example, plants in PB:PM were on average larger (height and growth index) than plants in PB that had been grown for 30 additional days (data not shown).

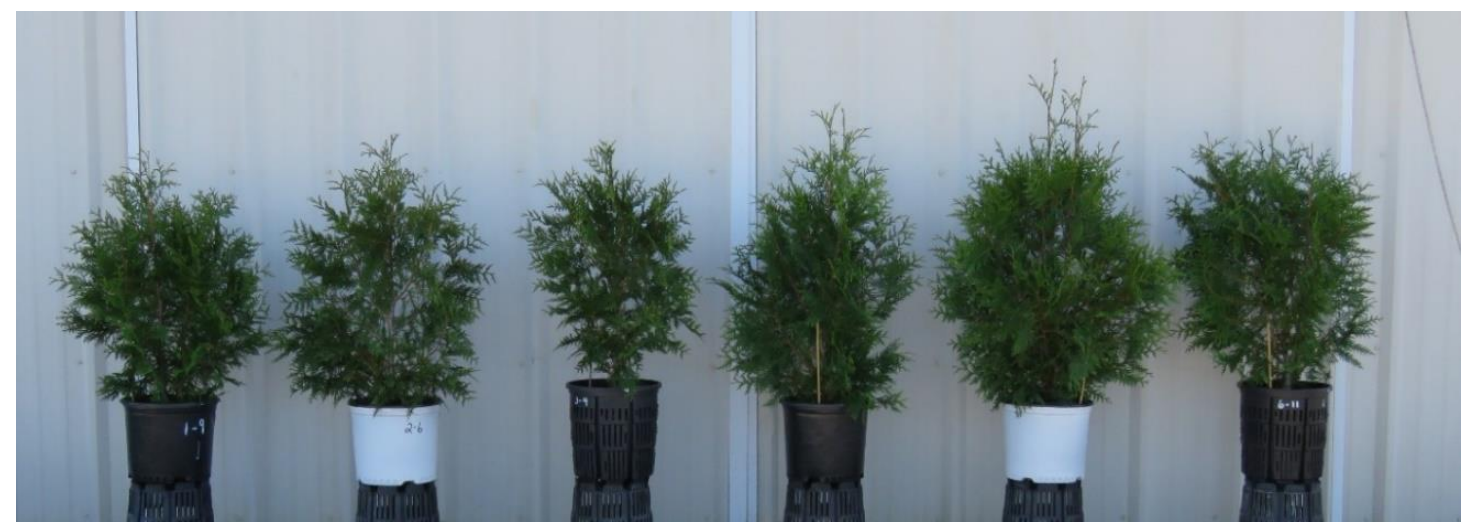

Figure 1. Representative 'Green Giant' arborvitae plants 173 days after planting (in Tennessee) in 100\% pine bark (three plants on left) and 4 pine bark: 1 peatmoss (v:v; three plants on right) in standard black, standard white, and air pruning containers (left to right within each substrate).

White containers provided lower RZT that likely reduced plant stress resulting in slightly larger and potentially healthier plants. White plastic containers are commercially available from a number of manufacturers in a variety of sizes (up to 11 or $19 \mathrm{~L}$ ). Modern white containers are high quality and typically manufactured with co-extruded black (interior) and white (exterior) plastic to prevent light diffusion through the container which was a problem with earlier products. Plants grown in air pruning containers tend to have better branched and more vigorous root systems that can improve transplant establishment and subsequent crop quality, but to prevent drying out they will require more frequent irrigation and possibly higher application rates compared with crops in traditional black containers. 
The impact of abiotic factors on crop growth has been well documented and developing methods for reducing root zone stress would improve root development, crop quality, and transplant success [21]. The interaction of factors such as container type, substrate, and moisture content must be considered when evaluating alternative production practices. Growers typically use a single substrate/container type for all the different crop species in production. Light-colored containers can effectively reduce RZT which may be especially important in temperature-sensitive species, but we found that using substrates with higher VWC had a greater effect on overall crop growth especially when used in white containers. Although 'Green Giant' arborvitae is highly adaptable to soil type and is considered a heat-tolerant plant, we demonstrated increased growth by modifying the substrate and container type. Growers should consider conducting small-scale evaluations to determine if a particular substrate/container combination works in their production system. When conducting small trials, growers should place each substrate/container combination in separate irrigation zones and adjust irrigation volume based on plant needs to ensure moisture is not a limiting factor.

Author Contributions: Conceptualization, A.L.W. and J.M.P.; methodology, A.L.W. and J.M.P.; formal analysis, A.L.W. and E.K.B.; investigation, A.L.W. and J.M.P.; writing-original draft preparation, A.L.W.; writing一review and editing, A.L.W., J.M.P., and E.K.B.; funding acquisition, A.L.W. All authors have read and agreed to the published version of the manuscript.

Funding: This research was supported the National Institute of Food and Agriculture (NIFA), United States Department of Agriculture (USDA) Evans-Allen grant, under award number TENX-1519-CCOCP.

Acknowledgments: The authors wish to thank Terry Kirby for assistance with data collection and project maintenance.

Conflicts of Interest: The authors declare no conflicts of interest.

\section{References}

1. Self, R.L.; Ward, H.S. Effects of high soil temperature on root growth of loquat seedlings in nursery containers. Plant Dis. Report. 1956, 40, 957-959.

2. Martin, C.A.; Ingram, D.L.; Neil, T.A. Supraoptimal root-zone temperature alters growth and photosynthesis of holly and elm. J. Arboric. 1989, 15, 272-276.

3. Markham, J.W.; Bremer, D.J.; Boyer, C.R.; Schroeder, K.R. Effect of container color on substrate temperatures and growth of red maple and redbud. HortScience 2011, 46, 721-726. [CrossRef]

4. Ingram, D.L.; Ruter, J.M.; Martin, C.A. Review: Characterization and impact of supraoptimal root-zone temperatures in container-grown plants. HortScience 2015, 50, 530-539. [CrossRef]

5. Mathers, H.M. Summary of temperature stress issues in nursery containers and current methods of protection. HortTechnology 2003, 13, 617-624. [CrossRef]

6. Li, T.; Bi, G.; Harkness, R.L.; Denny, G.C.; Blythe, E.K.; Zhao, X. Nitrogen rate, irrigation frequency, and container type affect plant growth and nutrient uptake of Encore azalea 'Chiffon'. HortScience 2018, 53, 560-566. [CrossRef]

7. Nambuthiri, S.; Geneve, R.L.; Sun, Y.; Wang, X.; Fernandez, R.T.; Niu, G.; Bi, G.; Fulcher, A. Substrate temperature in plastic and alternative nursery containers. HortTechnology 2015, 25, 50-56. [CrossRef]

8. Arnold, M.A.; McDonald, G.V. Accelerator containers alter plant growth and the root-zone environment. J. Environ. Hortic. 1999, 7, 168-173.

9. Altland, J.E.; Locke, J.C.; Krause, C.R. Influence of pine bark particle size and pH on cation exchange capacity. HortTechnology 2014, 24, 554-559. [CrossRef]

10. Robbins, J.A.; Evans, M.R. Growing Media for Container Production in a Greenhouse or Nursery Part I. Available online: https://www.uaex.edu/publications/PDF/FSA-6097.pdf (accessed on 21 October 2019).

11. Altland, J.E.; Owen, J.S., Jr.; Jackson, B.E.; Fields, J.S. Physical and hydraulic properties of commercial pine-bark substrate products used in production of containerized crops. HortScience 2018, 53, 1883-1890. [CrossRef]

12. Gilman, E.F.; Watson, D.G. Thuja occidentalis White-Cedar. Available online: https://edis.ifas.ufl.edu/pdffiles/ ST/ST62900.pdf (accessed on 21 October 2019). 
13. Griffin, J.J.; Blazich, F.A.; Ranney, T.G. Propagation of Thuja x 'Green Giant' by stem cuttings: Effects of growth stage, type of cutting, and IBA treatment. J. Environ. Hortic. 1998, 16, 212-214. [CrossRef]

14. LeBude, A.V.; Bilderback, T.E. Pour-through Extraction Procedure: A Nutrient Management Tool for Nursery Crops. Available online: https://content.ces.ncsu.edu/the-pour-through-extraction-procedure-a-nutrientmanagement-tool-for-nursery-crops (accessed on 21 October 2019).

15. Fonteno, W.C.; Harden, C.T. North Carolina State University Horticultural Substrates Lab Manual. Available online: https://projects.ncsu.edu/project/hortsublab/pdf/porometer_manual.pdf (accessed on 15 December 2019).

16. Bilderback, T.; Boyer, C.; Chappell, M.; Fain, G.; Fare, D.; Gilliam, C.; Jackson, B.E.; Lea-Cox, J.; LeBude, A.V.; Niemiera, A.; et al. Best Management Practices: Guide for Producing Nursery Crops, 3rd ed.; Southern Nursery Association: Acworth, GA, USA, 2013.

17. Fields, J.S.; Fonteno, W.C.; Jackson, B.E.; Heltman, J.L.; Owen, J.S. Hydrophysical properties, moisture retention, and drainage profiles of wood and traditional components for greenhouse substrates. HortScience 2014, 49, 827-832. [CrossRef]

18. Johnson, C.R.; Midcap, J.T.; Hamilton, D.F. Evaluation of potting-media, fertilizer source, and rate of application on chemical composition and growth of Ligustrum japonicum Thumb. Sci. Hortic. 1981, 14, 157-163. [CrossRef]

19. Amoroso, G.; Frangi, P.; Piatti, R.; Fini, A.; Ferrini, F. Effect of mulching on plant and weed growth, substrate water content, and temperature in container-grown giant arborvitae. HortTechnology 2010, 20, 957-962. [CrossRef]

20. Martin, C.A.; Ingram, D.L. Evaluation of thermal properties and effect of irrigation on temperature dynamics in container media. J. Environ. Hortic. 1991, 9, 24-28.

21. Mathers, H.M.; Lowe, S.B.; Scagel, C.; Struve, D.K.; Case, L.T. Abiotic factors influencing root growth of woody nursery plants in containers. HortTechnology 2007, 17, 151-162. [CrossRef]

(C) 2020 by the authors. Licensee MDPI, Basel, Switzerland. This article is an open access article distributed under the terms and conditions of the Creative Commons Attribution (CC BY) license (http://creativecommons.org/licenses/by/4.0/). 